\title{
Potential and Limitations of Feedback-Supported Gait Retraining in Users of Lower Limb Prostheses
}

\author{
Kaitlyn Marie Rayl ${ }^{1}$ and Goeran Fiedler ${ }^{2, *(D)}$ \\ 1 Department of Physical Therapy, University of Pittsburgh, Pittsburgh, PA 15260, USA; kmr155@pitt.edu \\ 2 Department of Rehabilitation Science and Technology, University of Pittsburgh, Pittsburgh, PA 15260, USA \\ * Correspondence: gfiedler@pitt.edu; Tel.: +1-412-624-6475
}

Citation: Rayl, K.M.; Fiedler, G.

Potential and Limitations of

Feedback-Supported Gait Retraining in Users of Lower Limb Prostheses.

Prosthesis 2021, 3, 181-189. https://

doi.org/10.3390/prosthesis3020018

Academic Editor: Ugo D’Amora

Received: 14 May 2021

Accepted: 15 June 2021

Published: 21 June 2021

Publisher's Note: MDPI stays neutral with regard to jurisdictional claims in published maps and institutional affiliations.

Copyright: (c) 2021 by the authors. Licensee MDPI, Basel, Switzerland. This article is an open access article distributed under the terms and conditions of the Creative Commons Attribution (CC BY) license (https:/ / creativecommons.org/licenses/by/ $4.0 /)$.

\begin{abstract}
The outcomes of prosthetic rehabilitation after lower limb loss are, in large part, affected by the effectiveness of the provided gait retraining. The noted prevalence of adverse long-term effects, such as further joint and muscle degeneration, suggests that traditional rehabilitation programs have limitations. Recent advances in technology and in the understanding of motor learning promise the potential for better gait retraining interventions. This article reviews current literature on systems and methodologies of improving gait parameters in those with lower limb prostheses via exercise programs and various biofeedback systems. A total of 13 articles were included in the qualitative analysis. Findings indicate that many of the investigated systems are able to effectively analyze and change gait in the target population, but there remain considerable gaps in the knowledge. It has been noted that feedback modalities and dosage must be customized based on patient characteristics and rehabilitation goals, yet there is currently not enough published evidence to inform such customization.
\end{abstract}

Keywords: amputee gait; biofeedback systems; feedback; gait asymmetry

\section{Introduction}

Limb loss is not only a change in one's physical body, but a life-altering event that can affect a person's social, emotional, and mental aspects of their life as well. Currently, an estimated 2 million people in the United States are living with limb loss, a number that is predicted to reach 3.6 million by 2050 [1]. The high prevalence of limb loss and an anticipated increase thereof makes improved rehabilitation after limb loss an important public health priority. Effectively reducing adverse short-term and long-term effects of limb loss has the potential to benefit a large patient population's overall quality of life.

The typical rehabilitation process following lower limb loss, including the prescription and fitting of prosthetic devices, has been refined through, among other things, Clinical Practice Guidelines by the Department of Veterans Affairs and Department of Defense [2]. These Practice Guidelines outline the phases of rehabilitation, a multidisciplinary approach, and recommend a continuum of lifelong care following amputation. The phases include the perioperative, pre-prosthetic, prosthetic training, and lifelong care [2]. Yet, in many typical settings, there are inevitable limitations in time, resources, and money that pose practical challenges to instituting an ideal rehabilitation process. For instance, the availability of a physical therapist who is an integral part in the prosthetic gait training process is often limited to the duration of a few prescribed training sessions, as is the space and equipment needed to provide the best care to their patients. The recommended long-term follow-ups are in many cases not feasible.

The noted limitations of available gait retraining interventions likely play a role in the high prevalence of gait deviations in lower limb prosthesis users. Changes in symmetry, compensatory muscle activation, and otherwise altered biomechanics can result in dynamic inefficiency, greater risk of injuries, and, by extension, overall higher long-term healthcare costs. Among the most common gait deviations prosthesis users can develop are 
asymmetrical single leg stance time on the prosthetic limb and increased vertical ground reaction forces onto the intact $\operatorname{limb}[3,4]$. The consequences of these abnormal walking behaviors are increased energy expenditure, as well as decreased balance and abnormal force production on the body [5]. Both these and other gait deviations have been shown to lead to detrimental secondary long-term effects on the intact and residual limbs.

The risk of secondary musculoskeletal conditions has long been known to greatly impact quality of life of prosthesis users. These conditions can include, but are not limited to, chronic low back pain, osteoarthritis of the knee and hip joint of the intact limb, and even osteopenia and other degenerative changes of the residual limb [6]. Chronic low back pain can cause adverse effects on social, emotional, and physical health in those with limb loss [7]. These conditions have been attributed to the changes in biomechanics of a prosthetic user, improper fit of a prosthesis, and changes in the gait pattern resulting in unphysiological forces placed upon the spine and limbs [6]. It can be concluded that with proper and appropriately dosed gait training, the gait deviations at the root of these secondary conditions can be reduced to better preserve the body in the years following limb loss.

Gait analysis has been used as a tool to measure the biomechanical differences between, for instance, users and non-users of prosthetic devices. There are a variety of ways to analyze gait, from simple observation to the more complex approaches involving reflective markers, multiple designated cameras, and force plates. Gait analysis can help identify asymmetrical patterns and deviations, which is important throughout the rehabilitation process in prosthesis users. Studies that have compared normative ranges of gait measures between able-bodied populations and limb-loss populations have shown that significant deviations occur at the ankle, knee, and hip for prosthesis users [8]. A goal of identifying and correcting gait deviations early in prosthetic training is to alleviate many of the musculoskeletal impairments that arise later in life after prolonged prosthetic use.

One way that has been proposed to correct various gait deviations and enhance gait retraining is the use of feedback technology. Feedback technology has been shown to provide improvements to learning by giving the user information that effectively impacts motor planning in the brain [9]. Most popular during prosthetic gait training is the use of mirrors. Both cost effective and easily accessible, mirror therapy provides real-time visual feedback for prosthesis users. However, the mirror only provides one perspective that may not be most useful to assess gait quality. Furthermore, its applicability is limited to a specific environment, making it less useful in the natural environment outside of the training lab. Another approach that has been proposed is based on feedback utilizing visual or auditory technology. In a controlled laboratory setting, visual signals can be presented as graphs or symbols on a screen as a person walks on an instrumented treadmill and/or has sensors attached to measure gait parameters. Auditory feedback can notify a person via headphones that they are walking asymmetrically, for example [5].

This technology, like mirrors, is not easily transferable to environments outside the lab, and the needed equipment of treadmills, force plates, and computers along with the designated lab space tends to be prohibitively expensive for use in a typical clinical setting. The time requirements to attach and remove the reflective markers and potential other wearable devices is likewise not well compatible with the constraints of a typical therapy session. Accordingly, recent research has endeavored to address the lack of affordable technology that can be used in the clinic or community to provide feedback to a lower limb prosthesis user in order to improve gait symmetry and reduce gait deviations. A recent review of biofeedback systems for lower limb amputees evaluated various system designs, gait and biomechanical parameters, and clinical and technical effectiveness of the technology in this population [10]. While providing a comprehensive review of the current literature, the authors point out the need for additional research to generate recommendations on appropriate feedback modalities and dosages for different gait deviations, participants' characteristics, and stages of the gait rehabilitation continuum. To our knowledge, there are 
no current reviews of biofeedback systems that focus on these parameters, or generally on the effectiveness in free-living environments.

In summary, there is a great variety of approaches to improving prosthetic gait retraining, the comparative effectiveness of which is not always well established. In order to make clinical decisions that facilitate optimal patient outcomes, it is important to consider a wide range of available options for interventions. Given the relative scarcity of pertinent research literature, an assessment based on narrowly defined technical or other specific parameters may improve direct comparability between options but risks missing promising alternative approaches outside the narrow scope.

With advances in consumer electronics, such as smartphones, increasing the affordability and ubiquity of powerful data collection and processing technology, there is an opportunity to make feedback technology to improve gait retraining in prosthesis users more accessible. Benefits would extend to the healthcare system as gait training provided by clinicians becomes more cost effective and results in better long-term outcomes. Considering the rapid pace of development in this area, the current paper provides an updated review of the literature on affordable real time feedback technology to assist lower limb prosthesis gait retraining. It was the aim of this literature review to identify the most promising approaches, not limited to a specific variety, as well as their current shortcomings when compared to typical rehabilitation strategies with a physical therapist.

\section{Results}

Using MEDLINE (PubMed), 88 results were originally found when using the primary search terms. Those results were refined and narrowed by adjusting the search terms used, rendering 23 results. Given the necessity to cover any other missing articles, the terms were then adjusted again to result in 27 records (Figure 1). Exclusion by publication language and date removed five titles. Screening abstracts resulted in a further six full-text articles being excluded for irrelevance to the subject (e.g., not including persons with limb loss as part of the patient population). Three articles were deemed as not relevant following closer examination of the abstract. The remaining 13 articles were included in qualitative synthesis and quantitative synthesis.

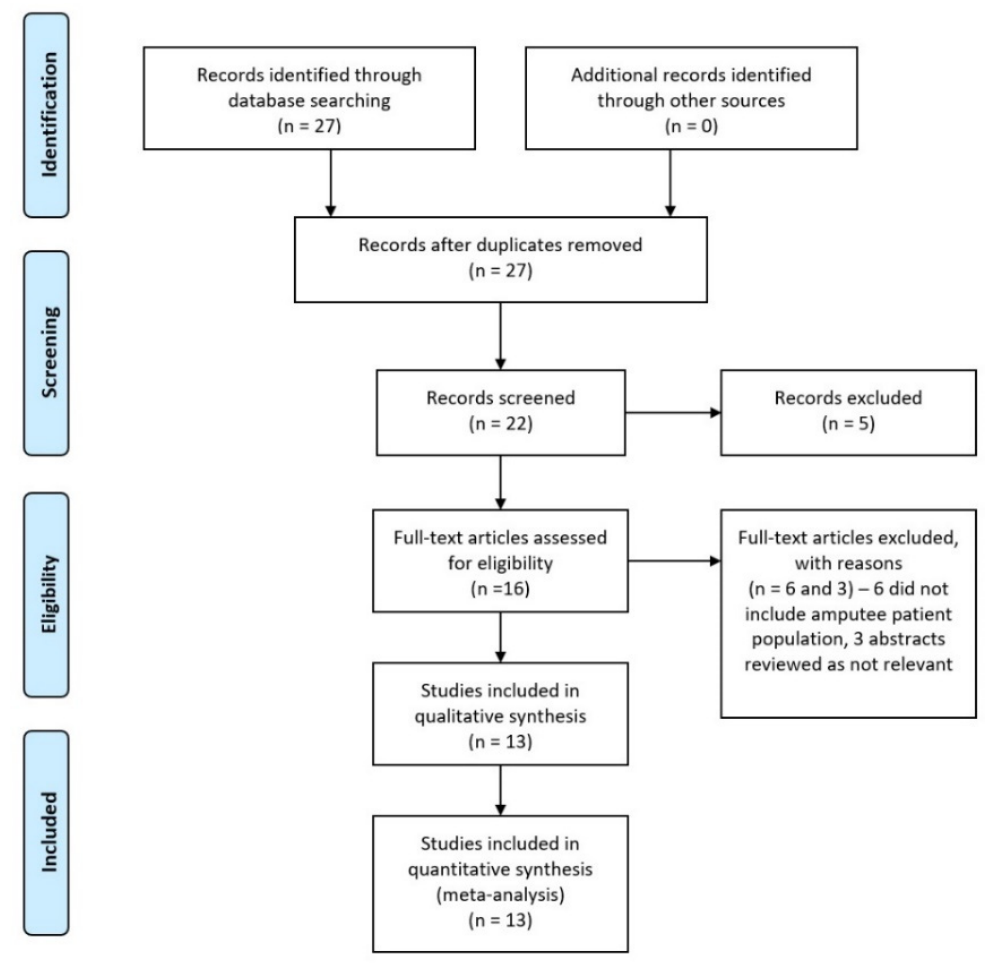

Figure 1. PRISMA flow diagram. 


\subsection{Participant Demographics}

Throughout the studies included in this review, the range of age for participants was 20 years old [11] to 80 years old [12]. Previous systematic reviews noted the lack of pediatric studies of lower limb loss as a limitation of recent research [10], which is confirmed by our review as well. That children may have different responses to feedback training than adults is suggested by the finding that amputees who were younger and/or higher functioning, such as active military members, tended to have less significant improvement of results with biofeedback systems and other gait training methods [12,13].

The reason for lower limb amputation (LLA) varied widely across all studies and within studies, with the level of amputation also varying greatly. Some studies were exclusively patients with transfemoral amputation (TFA) [14], or transtibial amputation (TTA) [15], while others included both TTA, TFA, and unilateral and bilateral amputations [13]. Able bodied controls were only used in two studies [15], and were included in one of the systematic reviews [10]. The level of amputation did not appear to affect outcomes from person to person in studies. Some studies with participants who had bilateral limb loss implemented biofeedback methods to both limbs [12], which may have resulted in different outcomes compared to those with unilateral LLA. Many studies in this review, as well as other articles, reflect the difficulties in recruitment of certain patient populations within prosthetics and amputations studies, thus inclusion criteria regarding cause and level of amputation are often broad in order to have enough participants to conduct the study (Figure 2).

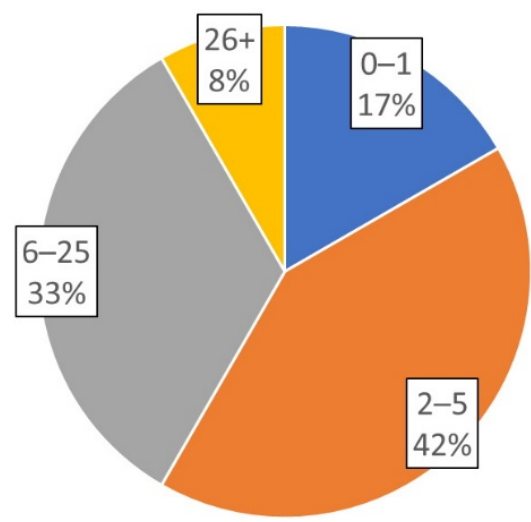

Figure 2. Distribution of sample sizes in included studies.

\subsection{Use of Varying Feedback Devices}

Feedback devices used in the reviewed studies varied widely, including visual, auditory, tactile, and implanted types, yet most appeared to have at least some positive effect on gait parameters in participants with LLA. Visual feedback systems included Computer Assisted Rehabilitation Environment (CAREN) systems to improve gait parameters [15]. Studies that utilized auditory feedback in real-time found positive effects on gait symmetry [12], a conclusion that confirms that of a previous systematic review by Highsmith et al., who stated that utilizing auditory feedback in gait intervention is effective in improving gait [16]. Vibrotactile feedback was used in multiple studies in various ways. Stance time was improved with wearable vibrotactile feedback throughout the gait cycle [13]. Martini et al., also found that using a wearable vibrotactile feedback device improved temporal symmetry [17]. Vibrotactile feedback was associated with reduced energy consumption in the case study by Wang et al., 2020 [18]. Another feedback device was based on implanted intraneural stimulation electrodes, which were found to improve walking speed and self-reported walking confidence [19].

While most studies found positive impacts using various feedback systems, this was not without exception, as another vibrotactile feedback system to improve gait and stance times, the Electrotactile Moving Sensation for Sensory Augmentation (EMSSA), 
actually had a negative effect on postural control, reduced gait efficiency, and had no effect on gait parameters [20].

\subsection{Cost Effectiveness and Useability}

While the use of biofeedback systems appears to positively affect gait parameters, energy expenditure, and quality of life in those with LLA in a laboratory environment, the cost and practical feasibility of these various systems varies. Gaunaurd et al. in 2020 assessed the feasibility of using a mobile application device as a way to provide at-home accessible feedback throughout the day [12]. Other studies, such as those by Darter and Wilken, 2011, and by Beurskens et al., 2014, utilized the CAREN system, the use of which is generally limited to research studies, given its permanent installation, large size, and high cost $[14,15]$. Implanted neuro-sensory feedback restoration, such as that evaluated by Petrini et al., 2019, poses the common risks of surgical procedures during and between implantation and removal [19]. There still remains a dearth of evidence on smaller, accessible, and minimally invasive devices to improve gait.

As an alternative to feedback systems, two articles assessed how exercise programs impact gait parameters in those with lower limb loss [12]. While Gaunaurd et al., 2020 examined an exercise program in conjunction with a mobile device app with real-time auditory feedback, Schafer et al., 2021, utilized a standalone 12-week program. Both groups were successful in finding improvements with postural control and gait quality. This may suggest that an individual exercise program in conjunction with biofeedback systems may increase retention of improved gait patterns in those with LLA.

\subsection{Levels of Evidence}

In using the levels of evidence from prognostic studies adapted from the American Society of Plastic surgeons [21], the average level of evidence from the articles reviewed was III, with a range from I to V (Figure 3). While there are limitations to accepting articles deemed as lower-level evidence because of their study design, it should be noted that research on prosthetics and LLA rehabilitation often have small sample sizes and heterogeneous participant demographics, which leads to many case control studies. In emerging research areas, such as that of feedback system studies for those with LLA, seeing early research dominated by case studies, case control studies, and pilot studies is to be expected.



Figure 3. Levels of evidence (I-V) of reviewed studies. 


\section{Discussion}

\subsection{Summary of Evidence}

Many studies found improvements of some degree to gait parameters and energy consumption when using feedback devices or implementing plans that directly address individualized gait deviations in those with LLA.

\subsection{Interpretation in the Context of Previous Literature}

Study findings align well with results reported in the recent research literature. Two comparable review articles concluded that "the use of biofeedback ... has the same or a better effect compared to existing interventions" [22] and "[biofeedback] systems need to appropriately align feedback modalities and strategies with measured gait parameters" [10].

The sample size of 13 included articles in this study is not unusual in the field of prosthetic rehabilitation. Comparable review studies had sample sizes of nine [18] to 41 [23].

\subsection{Limitations}

The relatively small number of articles found to meet the inclusion criteria for this review suggests that the used database used may not have contained all available publications, and that a future review study would benefit from a more in-depth and expansive review across multiple databases. Given the small sample size of participants across the included articles, a meta-analysis on demographics or outcome measures could not be completed. Two reviewers assessed each article in an attempt to limit the risk of bias.

\section{Materials and Methods}

To review the literature on affordable real-time feedback technology to assist lower limb prosthetic gait training, the following search items were entered in December 2020 into MEDLINE (PubMed): “(((amputation) OR (amputee) OR (prosthetic) AND (gait)) AND (feedback) AND training)". Articles were then sifted using the following exclusion criteria: articles published prior to 2010, foreign language articles, and studies without human subjects. Articles that did not include prosthesis users in their sample population were excluded as well. Additional articles were excluded based on abstract review for relevance and appropriateness to the subject. Of the remaining articles, each was subsequently assessed for quality using the Preferred Reporting Items for Systematic Reviews and MetaAnalyses (PRISMA) guidelines. Using the PRISMA guidelines, included articles are listed in Table 1. Levels of evidence were ranked for each article using the Levels of Evidence for Prognostic Studies [21].

Table 1. Overview of articles included in the review ordered alphabetically by first author name. ( $\mathrm{n}$-sample size, LoE-level of evidence, TTA — transtibial amputee, TFA—transfemoral amputee, SSWS—self-selected walking speed, LLA—lower limb amputation, $10 \mathrm{mWT}-10 \mathrm{~m}$ walk test, $6 \mathrm{MWT}-6 \mathrm{~min}$ walk test, TUG-timed up and go test, CHAMP-comprehensive high level amputee mobility predictor, GRF-ground reaction force, $\mathrm{COP}$ - center of pressure, RCT—randomized controlled trial, POMA—performance-oriented mobility assessment).

\begin{tabular}{|c|c|c|c|c|c|c|}
\hline Article Author(s) & $\begin{array}{c}\text { Intervention, Study } \\
\text { Design }\end{array}$ & $\mathbf{n}$ & $\begin{array}{l}\text { Study Sample } \\
\text { Characteristics }\end{array}$ & Outcome Variables & Main Study Results & LoE \\
\hline $\begin{array}{l}\text { Beurskens et al., } \\
2014 \text { [15] }\end{array}$ & $\begin{array}{l}\text { Balance and visual } \\
\text { perturbations effects on gait, } \\
\text { case control }\end{array}$ & 22 & $\begin{array}{c}9 \text { unilateral TTA } \\
\text { active-duty military } \\
\text { personnel } \\
13 \text { able-bodied } \\
\text { controls }\end{array}$ & $\begin{array}{l}\text { Step length, } \\
\text { step width, } \\
\text { trunk stability }\end{array}$ & $\begin{array}{l}\text { Both groups exhibited wider } \\
\text { and shorter steps with } \\
\text { perturbations. Step width } \\
\text { variability greater for TTA } \\
\text { than control. }\end{array}$ & III \\
\hline $\begin{array}{c}\text { Darter and } \\
\text { Wilken, } 2011 \text { [14] }\end{array}$ & $\begin{array}{l}\text { 12-session gait training } \\
\text { program with real time } \\
\text { visual feedback, case study }\end{array}$ & 1 & 24-year-old TFA & $\begin{array}{l}\text { SSWS, step length, } \\
\text { step width, stance } \\
\text { time, } \\
\text { oxygen uptake }\end{array}$ & $\begin{array}{l}\text { Improvements in trunk } \\
\text { rotation, trunk lean, hip } \\
\text { abduction, hip torque, and } \\
\text { foot position. Decreased } \\
\text { oxygen consumption. }\end{array}$ & IV \\
\hline
\end{tabular}


Table 1. Cont.

\begin{tabular}{|c|c|c|c|c|c|c|}
\hline Article Author(s) & $\begin{array}{l}\text { Intervention, Study } \\
\text { Design }\end{array}$ & $\mathbf{n}$ & $\begin{array}{l}\text { Study Sample } \\
\text { Characteristics }\end{array}$ & Outcome Variables & Main Study Results & LoE \\
\hline $\begin{array}{l}\text { Escamilla-Nunez } \\
\text { et al., } 2020 \text { [13] }\end{array}$ & $\begin{array}{l}\text { Gait training with and } \\
\text { without wearable } \\
\text { vibrotactile feedback system, } \\
\text { comparison study }\end{array}$ & 5 & $\begin{array}{l}3 \text { TFA, } 1 \text { TTA, } 1 \\
\text { bilateral (TF/TT) } \\
\text { from vascular (1), } \\
\text { traumatic (3), and } \\
\text { congenital (1) } \\
\text { causes }\end{array}$ & $\begin{array}{l}\text { Stance time, } \\
\text { perceived usability } \\
\text { of feedback system }\end{array}$ & $\begin{array}{l}\text { Improved stance time with } \\
\text { feedback. }\end{array}$ & IV \\
\hline $\begin{array}{l}\text { Escamilla-Nunez } \\
\text { et al., } 2020 \text { [10] }\end{array}$ & $\begin{array}{l}\text { Biofeedback systems for gait } \\
\text { rehabilitation for LLA, } \\
\text { systematic review }\end{array}$ & $\mathrm{n} / \mathrm{a}$ & $\begin{array}{l}\text { TTA, TFA, } \\
\text { able-bodied } \\
\text { controls }\end{array}$ & $\begin{array}{l}\text { Gait parameters, } \\
\text { physical, } \\
\text { physiological, and } \\
\text { performance } \\
\text { variables, } \\
\text { self-report data }\end{array}$ & $\begin{array}{l}\text { Lacking evidence on } \\
\text { younger and pediatric } \\
\text { populations. Feedback } \\
\text { systems should be used } \\
\text { early in rehabilitation } \\
\text { process. }\end{array}$ & II \\
\hline $\begin{array}{l}\text { Gaunaurd et al., } \\
2020 \text { [12] }\end{array}$ & $\begin{array}{c}\text { Mobile Device } \\
\text { Outcomes-based } \\
\text { Rehabilitation Program } \\
\text { (MDORP), repeated } \\
\text { measures pilot study }\end{array}$ & 17 & $\begin{array}{l}\text { Veterans and } \\
\text { active-duty service } \\
\text { members with LLA } \\
\text { at different levels, } \\
\text { all higher } \\
\text { functioning. }\end{array}$ & $\begin{array}{c}\text { Gait kinematics and } \\
\text { timing variables, } 10 \\
\text { mWT, TUG, } \\
\text { CHAMP, 6 MWT }\end{array}$ & $\begin{array}{l}\text { Significant improvement in } \\
\text { residual limb hip extensor } \\
\text { strength, gait quality, and } \\
\text { endurance, basic and } \\
\text { high-level mobility. } \\
\text { Improvement in CHAMP } \\
\text { scores. }\end{array}$ & II \\
\hline $\begin{array}{c}\text { Gorsic et al., } 2014 \\
\text { [24] }\end{array}$ & $\begin{array}{l}\text { Gait phase detection and } \\
\text { feedback algorithm for a } \\
\text { robotic prosthesis, } \\
\text { evaluation study }\end{array}$ & 8 & $\begin{array}{l}3 \text { TFA, } 5 \\
\text { able-bodied } \\
\text { subjects }\end{array}$ & $\begin{array}{l}\text { GRF, COP, joint } \\
\text { angles, angular } \\
\text { velocity }\end{array}$ & $\begin{array}{l}\text { High rate of detection of } \\
\text { four phases of gait, using } \\
\text { shoe insole sensors and } \\
\text { inertial measurement units. }\end{array}$ & IV \\
\hline $\begin{array}{l}\text { Highsmith et al., } \\
2016 \text { [16] }\end{array}$ & $\begin{array}{c}\text { Prosthetic gait training } \\
\text { interventions, literature } \\
\text { review }\end{array}$ & 229 & $\begin{array}{l}\text { Studies on } \\
\text { overground } \\
\text { training (13) and } \\
\text { treadmill } \\
\text { training (5) }\end{array}$ & $\begin{array}{l}\text { Gait biomechanics, } \\
\text { spatiotemporal } \\
\text { variables, walk } \\
\text { distance }\end{array}$ & $\begin{array}{l}8 \text { evidence statements, e.g., } \\
\text { Training with awareness } \\
\text { interventions improved gait. } \\
\text { Treadmill training is } \\
\text { effective with visual } \\
\text { feedback. }\end{array}$ & II \\
\hline $\begin{array}{l}\text { Martini et al., } \\
2021[17]\end{array}$ & $\begin{array}{l}\text { Wearable vibrotactile } \\
\text { sensory feedback to } \\
\text { influence LLA gait, pilot } \\
\text { study }\end{array}$ & 3 & TFA aged 53-71. & $\begin{array}{l}\text { Temporal gait } \\
\text { symmetry, gait } \\
\text { speed, spatial } \\
\text { symmetry index }\end{array}$ & $\begin{array}{l}\text { Improved temporal } \\
\text { symmetry after three } \\
\text { training sessions. One } \\
\text { subject retained } \\
\text { improvements without the } \\
\text { feedback device. }\end{array}$ & IV \\
\hline $\begin{array}{c}\text { Pagel et al., } 2016 \\
{[20]}\end{array}$ & $\begin{array}{c}\text { Electrotactile Moving } \\
\text { Sensation for Sensory } \\
\text { Augmentation (EMSSA), } \\
\text { case series }\end{array}$ & 3 & $\begin{array}{l}\text { Male TFAs, aged } 21, \\
54 \text {, and } 73 \text { years. } \\
\text { Causes: trauma ( } 2), \\
\text { bone cancer. }\end{array}$ & $\begin{array}{l}\text { Postural control } \\
\text { symmetry, step } \\
\text { length ratio, step } \\
\text { duration ratio }\end{array}$ & $\begin{array}{l}\text { EMSSA decreased standing } \\
\text { stability, minimally } \\
\text { improved gait symmetry. } \\
\text { One participant improved } \\
\text { step length with sensory } \\
\text { feedback. }\end{array}$ & IV \\
\hline $\begin{array}{c}\text { Petrini et al., } 2019 \\
\text { [19] }\end{array}$ & $\begin{array}{c}\text { Implanted neural sensory } \\
\text { feedback restoration, pilot } \\
\text { study }\end{array}$ & 2 & $\begin{array}{l}\text { TFA from trauma, } \\
\text { implanted with four } \\
\text { intraneural } \\
\text { stimulation } \\
\text { electrodes. }\end{array}$ & $\begin{array}{l}\text { Oxygen uptake, gait } \\
\text { speed, self-reported } \\
\text { pain, confidence }\end{array}$ & $\begin{array}{l}\text { Speed and confidence } \\
\text { improved, mental fatigue, } \\
\text { pain, and metabolic } \\
\text { consumption decreased } \\
\text { with neural stimulation } \\
\text { trials. }\end{array}$ & IV \\
\hline $\begin{array}{c}\text { Schafer and } \\
\text { Vanicek, } 2020[25]\end{array}$ & $\begin{array}{l}\text { 12-week personalized } \\
\text { exercise program, RCT }\end{array}$ & 14 & $\begin{array}{l}10 \text { TFA, } 4 \text { TTA. } \\
\text { Mean age } 60 \text { years } \\
\text { in exercise, } 63 \text { in } \\
\text { control group } \\
(n=7) .\end{array}$ & $\begin{array}{l}\text { Postural responses } \\
\text { to perturbations, } \\
\text { symmetry, } \\
\text { confidence }\end{array}$ & $\begin{array}{l}\text { Improvements in postural } \\
\text { control, equilibrium and } \\
\text { strategy scores, reduced } \\
\text { reliance on visual input } \\
\text { post-intervention. }\end{array}$ & I \\
\hline $\begin{array}{c}\text { Wang et al., } 2020 \\
\text { [11] }\end{array}$ & $\begin{array}{l}\text { Tactile vibration feedback } \\
\text { system, case report }\end{array}$ & 1 & $\begin{array}{l}20 \text {-year-old male } \\
\text { with traumatic TTA. }\end{array}$ & $\begin{array}{l}\text { Tinetti POMA, gait } \\
\text { analysis, in- and } \\
\text { outdoor, energy } \\
\text { consumption. }\end{array}$ & $\begin{array}{l}\text { Improved gait scores, stance } \\
\text { time, single leg support } \\
\text { time, step length, stride } \\
\text { length. Decreased energy } \\
\text { consumption. }\end{array}$ & V \\
\hline $\begin{array}{c}\text { Yang et al., } 2012 \\
{[5]}\end{array}$ & $\begin{array}{l}\text { In-shoe gait detection for } \\
\text { real-time auditory feedback, } \\
\text { evaluation study }\end{array}$ & 3 & $\begin{array}{l}\text { TTAs. Average age } \\
49.7 \text { years. }\end{array}$ & $\begin{array}{l}\text { Gait symmetry } \\
\text { ratio, trunk sway }\end{array}$ & $\begin{array}{l}\text { Improved gait symmetry, } \\
\text { trunk sway in } 2 \text { of } 3 \\
\text { participants following six } \\
\text { training sessions. }\end{array}$ & IV \\
\hline
\end{tabular}




\section{Conclusions}

Recent advances in consumer electronics technology have helped improve the capabilities of biofeedback systems for the purposes of gait retraining after limb loss. However, an effective, universally applicable, and cost-effective approach that is compatible with other healthcare interventions and real-life environments has not yet been developed or tested. Individual customization of feedback and refinement of interface technology to improve the information content of the feedback signal appear to be the most promising avenues to addressing this gap.

Author Contributions: Conceptualization, K.M.R. and G.F.; methodology, K.M.R.; formal analysis, K.M.R.; investigation, K.M.R.; resources, G.F.; data curation, K.M.R.; writing-original draft preparation, K.M.R.; writing-review and editing, G.F.; supervision, G.F.; project administration, G.F.; funding acquisition, G.F. All authors have read and agreed to the published version of the manuscript.

Funding: This research was funded by a Pitt/UPMC Rehabilitation Institute Pilot Grant.

Institutional Review Board Statement: Not applicable.

Informed Consent Statement: Not applicable.

Conflicts of Interest: The authors declare no conflict of interest.

\section{References}

1. Ziegler-Graham, K.; MacKenzie, E.J.; Ephraim, P.L.; Travison, T.G.; Brookmeyer, R. Estimating the Prevalence of Limb Loss in the United States: 2005 to 2050. Arch. Phys. Med. Rehabil. 2008, 89, 422-429. [CrossRef]

2. Webster, J.B.; Crunkhorn, A.; Sall, J.; Highsmith, M.J.; Pruziner, A.; Randolph, B.J. Clinical Practice Guidelines for the Rehabilitation of Lower Limb Amputation: An Update from the Department of Veterans Affairs and Department of Defense. Am. J. Phys. Med. Rehabil. 2019, 98, 820-829. [CrossRef] [PubMed]

3. Lemaire, E.D.; Fisher, F.R. Osteoarthritis and elderly amputee gait. Arch. Phys. Med. Rehabil. 1994, 75, 1094-1099. [CrossRef]

4. Pruziner, A.L.; Werner, K.M.; Copple, T.J.; Hendershot, B.D.; Wolf, E.J. Does Intact Limb Loading Differ in Servicemembers with Traumatic Lower Limb Loss? Clin. Orthop. Relat. Res. 2014, 472, 3068-3075. [CrossRef] [PubMed]

5. Yang, L.; Dyer, P.; Carson, R.; Webster, J.; Foreman, K.B.; Bamberg, S. Utilization of a lower extremity ambulatory feedback system to reduce gait asymmetry in transtibial amputation gait. Gait Posture 2012, 36, 631-634. [CrossRef]

6. Gailey, R. Review of secondary physical conditions associated with lower-limb amputation and long-term prosthesis use. J. Rehabil. Res. Dev. 2008, 45, 15-30. [CrossRef]

7. Ephraim, P.L.; Wegener, S.T.; MacKenzie, E.J.; Dillingham, T.R.; Pezzin, L.E. Phantom Pain, Residual Limb Pain, and Back Pain in Amputees: Results of a National Survey. Arch. Phys. Med. Rehabil. 2005, 86, 1910-1919. [CrossRef]

8. Rábago, C.A.; Wilken, J.M. The Prevalence of Gait Deviations in Individuals with Transtibial Amputation. Mil. Med. 2016, 181, 30-37. [CrossRef]

9. An, W.W.; Ting, K.-H.; Au, I.P.; Zhang, J.H.; Chan, Z.Y.S.; Davis, I.S.; So, W.K.Y.; Chan, R.H.M.; Cheung, R.T.H. Neurophysiological Correlates of Gait Retraining with Real-Time Visual and Auditory Feedback. IEEE Trans. Neural Syst. Rehabil. Eng. 2019, 27, 1341-1349. [CrossRef]

10. Escamilla-Nunez, R.; Michelini, A.; Andrysek, J. Biofeedback Systems for Gait Rehabilitation of Individuals with Lower-Limb Amputation: A Systematic Review. Sensors 2020, 20, 1628. [CrossRef]

11. Wang, S.-Q.; Gao, Y.-Q.; Xu, Z.-H.; Xu, F.-Y.; Yuan, L. Effects of tactile vibration feedback system on balance function and walking ability of a unilateral transtibial amputee with a prosthesis: A case report. Medicine 2020, 99, e22450. [CrossRef] [PubMed]

12. Gaunaurd, I.; Gailey, R.; Springer, B.; Symsack, A.; Clemens, S.; Lucarevic, J.; Kristal, A.; Bennett, C.; Isaacson, B.; Agrawal, V.; et al . The Effectiveness of the DoD/VA Mobile Device Outcomes-Based Rehabilitation Program for High Functioning Service Members and Veterans with Lower Limb Amputation. Mil. Med. 2020, 185, 480-489. [CrossRef] [PubMed]

13. Escamilla-Nunez, R.; Michelini, A.; Andrysek, J. A Wearable Vibrotactile Biofeedback System Targeting Gait Symmetry of Lower-limb Prosthetic Users. In Proceedings of the 2020 42nd Annual International Conference of the IEEE Engineering in Medicine \& Biology Society (EMBC), Montreal, QC, Canada, 20-24 July 2020; pp. 3281-3284.

14. Darter, B.J.; Wilken, J.M. Gait Training with Virtual Reality-Based Real-Time Feedback: Improving Gait Performance Following Transfemoral Amputation. Phys. Ther. 2011, 91, 1385-1394. [CrossRef] [PubMed]

15. Beurskens, R.; Wilken, J.M.; Dingwell, J.B. Dynamic stability of individuals with transtibial amputation walking in destabilizing environments. J. Biomech. 2014, 47, 1675-1681. [CrossRef]

16. Highsmith, M.J.; Andrews, C.R.; Millman, C.; Fuller, A.; Kahle, J.T.; Klenow, T.D.; Lewis, K.L.; Bradley, R.C.; Orriola, J. Gait Training Interventions for Lower Extremity Amputees: A Systematic Literature Review. Technol. Innov. 2016, 18, 99-113. [CrossRef] 
17. Martini, E.; Cesini, I.; D'Abbraccio, J.; Arnetoli, G.; Doronzio, S.; Giffone, A.; Meoni, B.; Oddo, C.M.; Vitiello, N.; Crea, S. Increased Symmetry of Lower-Limb Amputees Walking with Concurrent Bilateral Vibrotactile Feedback. IEEE Trans. Neural Syst. Rehabil. Eng. 2021, 29, 74-84. [CrossRef]

18. Ülger, Ö.; Şahan, T.Y.; Çelik, S.E. A systematic literature review of physiotherapy and rehabilitation approaches to lower-limb amputation. Physiother. Theory Pract. 2018, 34, 821-834. [CrossRef] [PubMed]

19. Petrini, F.M.; Bumbasirevic, M.; Valle, G.; Ilic, V.; Mijović, P.; Čvančara, P.; Barberi, F.; Katic, N.; Bortolotti, D.; Andreu, D.; et al. Sensory feedback restoration in leg amputees improves walking speed, metabolic cost and phantom pain. Nat. Med. 2019, 25, 1356-1363. [CrossRef]

20. Pagel, A.; Arieta, A.H.; Riener, R.; Vallery, H. Effects of sensory augmentation on postural control and gait symmetry of transfemoral amputees: A case description. Med. Biol. Eng. Comput. 2016, 54, 1579-1589. [CrossRef]

21. Burns, P.B.; Rohrich, R.J.; Chung, K.C. The Levels of Evidence and Their Role in Evidence-Based Medicine. Plast. Reconstr. Surg. 2011, 128, 305-310. [CrossRef] [PubMed]

22. van Gelder, L.M.; Barnes, A.; Wheat, J.S.; Heller, B.W. The use of biofeedback for gait retraining: A mapping review. Clin. Biomech. 2018, 59, 159-166. [CrossRef] [PubMed]

23. Eshraghi, A.; Safaeepour, Z.; Geil, M.D.; Andrysek, J. Walking and balance in children and adolescents with lower-limb amputation: A review of literature. Clin. Biomech. 2018, 59, 181-198. [CrossRef]

24. Goršič, M.; Kamnik, R.; Ambrožič, L.; Vitiello, N.; Lefeber, D.; Pasquini, G.; Munih, M. Online Phase Detection Using Wearable Sensors for Walking with a Robotic Prosthesis. Sensors 2014, 14, 2776-2794. [CrossRef] [PubMed]

25. Schafer, Z.A.; Vanicek, N. A block randomised controlled trial investigating changes in postural control following a personalised 12-week exercise programme for individuals with lower limb amputation. Gait Posture 2021, 84, 198-204. [CrossRef] 